\title{
Bogusław Kaczmarczyk*
}

Państwowa Wyższa Szkoła Zawodowa w Sanoku

\section{Lukasz Popławski* $^{* *}$}

Uniwersytet Ekonomiczny w Krakowie

\section{KWANTYFIKACJA PRZESTRZENI PUBLICZNEJ NA PRZYKŁADZIE SANOKA}

\section{STRESZCZENIE}

W artykule przedstawiono zagadnienie kwantyfikacji przestrzeni publicznej i opłaty za wykorzystanie przestrzeni publicznej na przykładzie Sanoka. Obecne problemy związane z przestrzennym rozmieszczeniem reklam są traktowane różnorako, najczęściej nierozpatrywane z punktu ładu przestrzennego. Ta kwestia będąca w zakresie zainteresowania ekonomii przestrzennej jest często pomijana. W opracowaniu udowodniono, że opłata za wykorzystanie przestrzeni publicznej jest zasadna i nie obciąża przedsiębiorców w znaczący sposób, natomiast może być istotnym wpływem do budżetu samorządu.

Słowa kluczowe: rozwój lokalny, przestrzeń publiczna, samorząd

\section{Wprowadzenie}

Przestrzeń jest to „trójwymiarowa rozciągłość (obszar), posiadająca atrybuty jednorodności, nieskończoności i nieograniczoności, w której zachodzą wszystkie zjawiska

* Adres e-mail: b.kaczmarczyk@pro.onet.pl.

** Adres e-mail: rmpoplaw@gmail.com. 
fizyczne" (Becla, Czaja, 2004). Jest to również miejsce, gdzie znajdują się przedmioty materialne. Z punktu widzenia niniejszych rozważań ważne jest rozpatrywanie przestrzeni od strony przede wszystkim geograficznej, gdy jest ona ograniczona rzeczywistymi lub umownymi granicami związanymi z wyróżnionymi cechami przestrzennymi, które charakteryzują środowisko geograficzno-przyrodnicze wywierające wpływ na zakres oraz formy aktywności indywidualnej i społecznej człowieka (Popławski, 2009).

Korzyści z lokalizacji na poszczególnych obszarach można rozpatrywać z punktu widzenia różnych czynników, takich jak: ekonomiczne, społeczne, środowiskowe, przestrzenne, polityczne, a także podatkowe. Ich rola i struktura podlegały zmianie w kolejnych etapach rozwoju gospodarczego wywołanego postępem naukowo-technicznym, a zwłaszcza innowacyjnością. Na skutek pojawiania się nowych technologii, technik i sposobów organizacji produkcji, a także zmian w znaczeniu i funkcjonowaniu poszczególnych sektorów i działów gospodarki narodowej zaczęto inaczej postrzegać przestrzeń. $Z$ punktu widzenia mikroekonomicznego przestrzeń była zawsze istotnym elementem, zwłaszcza jako miejsce prowadzonej działalności gospodarczej. Zainteresowanie przestrzenią ma związek także z rozwojem lokalnym i regionalnym. W tym kontekście istotne znaczenie ma ład w przestrzeni, również w zakresie poszczególnych rodzajów działalności gospodarczej i instrumentów wsparcia. W rozwoju lokalnym ważnym zagadnieniem jest rozwój i wzrost społeczno-gospodarczy społeczności, która zamieszkuje dane terytorium. W obecnych warunkach dominuje koncepcja rozwoju trwałego (zrównoważonego), gdzie ład przestrzenny jest traktowany na równi z innymi ładami (Kryk, 1999, 2004; Borys, 2005). „Ład jest kategorią ekonomiczną o tyle, o ile stanowi element modelu, wzorca i teorii efektywnej gospodarki, pełniąc na przykład funkcje proefektywnościowe" (Meredyk, 2014, s. 26). W ten sposób, rozpatrując kwestie ładu w przestrzeni publicznej, poszukujemy instrumentów wspierających dany pożądany porządek lub stan. W przypadku prawidłowego wykorzystania przestrzeni publicznej mogą do tego służyć różne instrumenty oparte na formule czynszowej komercyjnego wykorzystania przestrzeni. Rozpatrując przestrzeń w działalności gospodarczej, nie sposób nie odnieść się do instytucji powoływanych przez państwo w celu realizacji zadań publicznych w tym zakresie, czyli ogólnie mówiąc - sektora publicznego.

Sektor publiczny to zbiór instytucji powoływanych przez państwo w celu realizacji zadań publicznych będących wyrazem funkcji państwa (Lubińska, 2010, s. 56). Jest ważnym elementem współczesnych gospodarek, ich częścią, która służy ogółowi i pełni w stosunku do społeczeństwa służebne funkcje (Szewczuk, Zioło, 2008, 
s. 18-19; Kleer, 2008, s. 34; Miłaszewicz, 2015, s. 127-135). Instytucje publiczne dzięki posiadanym instrumentom mogą wpływać na właściwe kształtowanie relacji gospodarczych przez regulacje rynkowe.

Regulacje rynkowe mogą być wprowadzane w zakresie pobudzania działań pożądanych, w omawianym przypadku w obrębie przeciwstawienia się zawłaszczeniu i niszczeniu przestrzeni publicznej. „Przestrzeń publiczna to obszar o szczególnym znaczeniu dla zaspokajania potrzeb mieszkańców, poprawy jakości ich życia i sprzyjający nawiązywaniu kontaktów społecznych ze względu na jego położenie oraz cechy funkcjonalno-przestrzenne" (Dz.U. 2012, poz. 647).

Obecnie to jednostki administracji publicznej są odpowiedzialne za prawidłowe kształtowanie ładu przestrzennego. To właśnie sektor publiczny w celu zapewnienia działań społecznie pożądanych w przestrzeni wykonuje część tej działalności gospodarczej lub zleca organizacjom pozarządowym kształtowanie porządku publicznego $\mathrm{w}$ zakresie przestrzeni. W ich władaniu są obszary terytorialne, które ze względu na swoją działalność wykorzystuje również sektor prywatny. Obecnie sektor prywatny właściwie nie odpowiada za wykorzystanie przestrzeni publicznej ani za prawidłowe jego kształtowanie na posiadanej nieruchomości. W literaturze przedmiotu wylicza się różne zadania publiczne, i tak Stanisław Owsiak (2006, s. 129-130) wymienia z tego obszaru takie jak: bezpieczeństwo wewnętrzne kraju, kontrola gospodarowania bogactwami naturalnymi, urządzenia z zakresu infrastruktury, transport i drogi lokalne, usługi komunalne, ład przestrzenny, utrzymanie czystości lub zieleni w gminach czy prowadzenie gospodarki leśnej.

W obrębie przestrzeni publicznej występują określone dobra. Jerzy Wilkin (2010, s. 42-47) klasyfikuje dobra na pięć grup: czyste dobra rynkowe, dobra klubowe, prywatne dobra wspólne, dobra merytoryczne oraz czyste dobra publiczne. Za dobra merytoryczne uważa się takie, w których występuje efektywność mechanizmów rynkowych i społecznych potrzeb dostarczania dóbr o charakterze publicznym. Cechy dóbr merytorycznych są następujące: zaspokajają potrzeby społeczne, mechanizm rynkowy nie zapewnia dostatecznej podaży dóbr publicznych i istnieje konieczność wsparcia lub publicznego finansowania. Dobra te odróżnia od dóbr publicznych to, że najczęściej są dostarczane przez podmioty prywatne, mają swoją cenę w przeciwieństwie do dóbr publicznych, a dostęp do nich jest ograniczony.

Innym istotnym elementem dotyczącym prawidłowego wykorzystania przestrzeni publicznej są między innymi kwestie podatkowe, które w zakresie omawia- 
nego problemu - zapłaty za wykorzystanie tej przestrzeni oraz wpływu na prawidłowe jej kształtowanie - nie były dotychczas rozpatrywane, dlatego są przedmiotem niniejszych rozważań. Celem artykułu jest przedstawienie problemu kwantyfikacji przestrzeni publicznej na przykładzie Sanoka.

\section{Wstępny opis projektu komercyjnego wykorzystania przestrzeni publicznej}

W trosce o dbałość Sanoka, a także uwzględniając Strategię Rozwoju Miasta, należy rozważyć (w kategorii propozycji) szeroko rozumiany aspekt reklam i innych nośników informacyjnych, w szczególności komercyjnych, zlokalizowanych w Sanoku. Wrażenia gospodarzy i mieszkańców oraz licznych turystów są następujące: reklamy w obecnym stanie rzeczy nie spełniają już funkcji informacyjnej mającej za zadanie wzbudzenie w klientach chęci nabycia określonej kategorii produktu, w tym produktu turystycznego. Ponadto są one źle umiejscowione, architektonicznie wadliwie zaprojektowane i często nie mają nic wspólnego z Sanokiem. Ten stan trwa od wielu lat - dokładnie od momentu, kiedy reklama wpisała się na trwałe w krajobraz Sanoka.

Na początku lat 90 . XX wieku zjawisko to nie było tak dokuczliwe, natomiast obecnie jednoznacznie należy stwierdzić, iż rynek reklam w sensie lokalizacji, wyglądu szaty graficznej wymaga ujednolicenia, korekty i modernizacji. Oczywiście zamiarem standaryzacji rynku reklamowego dla miasta nie jest eliminacja reklam jako takich. Reklama jest i zawsze będzie integralną częścią gospodarki wolnorynkowej, natomiast sposób i forma jej prezentacji jest poważnym zadaniem i wyzwaniem dla gospodarzy. Ponadto realizacja powyższego projektu zdecydowanie przyczyni się do poprawy wizerunku Sanoka jako miasta nowoczesnego, a co za tym idzie - do wzrostu konkurencyjności i wzmocnienia pozycji Sanoka w regionie oraz w Polsce.

Proponowane rozwiązanie jest rozwiązaniem $\mathbf{w}$ pelni systemowym, z zalożenia w pelni koalicyjnym, o wieloletniej perspektywie funkcjonowania. Opisany projekt ma swój głęboki sens ekonomiczny, to znaczy korzyści z wdrożenia są wielokrotnie większe niż koszty adaptacji, co przy ograniczonych budżetach samorządu ma fundamentalne znaczenie. Autorzy projektu mają na względzie cel nadrzędny, to znaczy dla Sanoka najistotniejszy jest jego wizerunek i dobro, a niniejszy projekt 
jest propozycją, jak połączyć piękno, przyrodę, niepowtarzalną kilkusetletnią architekturę oraz styl z otaczającą komercją. Projekt sanockich reklam w sensie propozycji standaryzacji zagospodarowania przestrzeni publicznej nawiązuje do programów sektorowych i prognoz krótkoterminowych. Po jego wdrożeniu ma on odgrywać rolę jednego $\mathrm{z}$ wielu dostępnych instrumentów finansowych na gruncie zarządzania i realizacji Strategii Rozwoju Sanoka.

\section{Metoda badania}

Przestrzeń publiczna w ujęciu zrównoważonym (Popławski, 2009, s. 61) jako dobro ogólne w wyniku komercyjnego wykorzystania podlega kwantyfikacji, ocenie finansowej (Filipiak, 2009, s. 13; 2011, s. 15) i wnioskowaniu dla rozkładu normalnego pomiędzy próbą a skończoną zbiorowością generalną (Steczkowski, 1995, s. 11; Zasępa, 1972, s. 11). Główne kierunki metody reprezentacyjnej opisu ilościowego przestrzeni publicznej przedstawiono na rysunku 1 .

Rysunek 1. Główne kierunki metody reprezentacyjnej opisu ilościowego przestrzeni publicznej

Cel badania - rozkład aktywnych nośników reklamowych w Sanoku wraz z wprowadzeniem opłaty czynszowej z tytułu komercyjnego wykorzystania przestrzeni publicznej

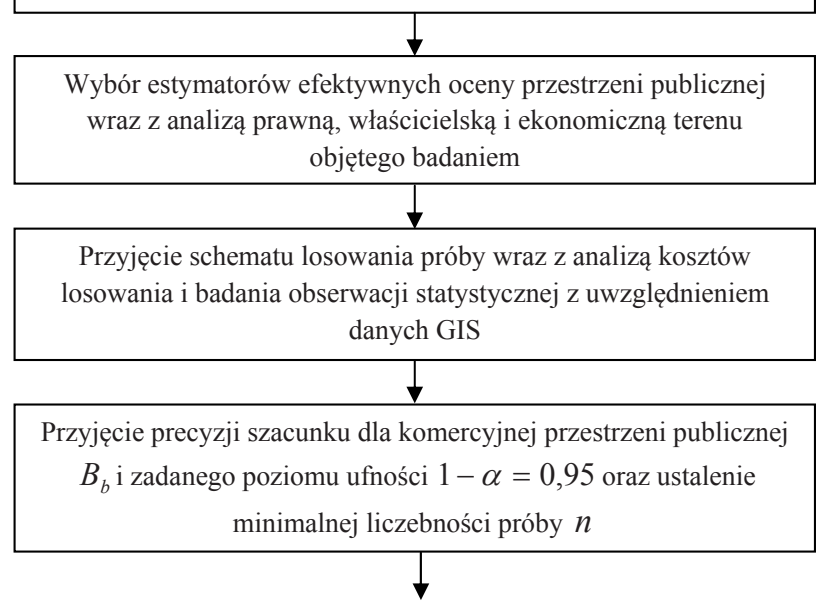




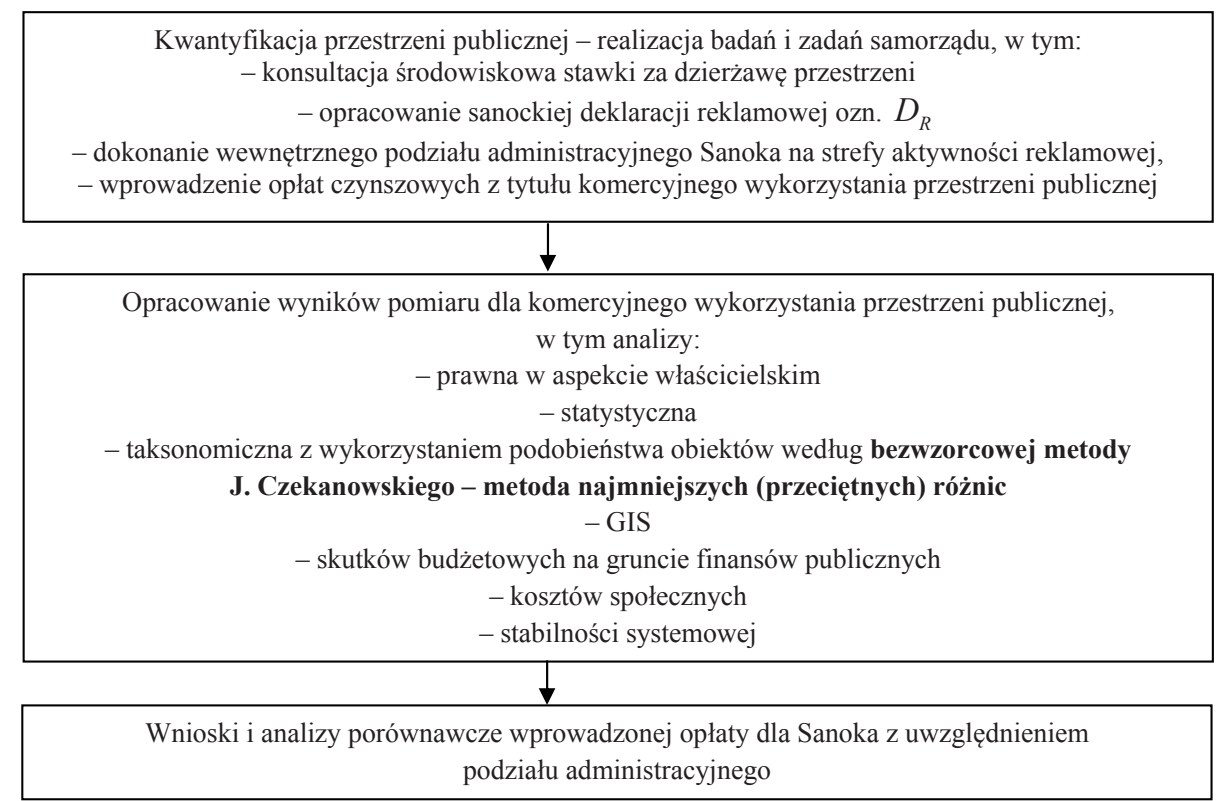

Źródło: opracowanie własne z uwzględnieniem: Zasępa (1972), Steczkowski (1995), Popławski (2009), Filipiak (2011).

\section{Określenie minimalnej liczebności próbki aktywnej powierzchni reklamowej}

Istotę pomiaru przestrzeni publicznej w ramach kompletnej wielowymiarowej kostki danych (KWKD) (Grabiński, 1994, s. 68 i n.) względem jej komercyjnego wykorzystania stanowi losowanie warstwowe (Neyman, 1934, s. 558-625; Steczkowski, 1995, s. 202 i n.), tak zwane stratyfikacyjne i branżowe, mające na celu jednolite wyodrębnienie stref aktywności reklamowych w ramach zbiorowości generalnej z przyjętą charakterystyką optymalizacyjną ${ }^{1}$, z uwzględnieniem porządkowych metod taksonomicznych (Grabiński, 2003, s. 93 i n.).

Przyjęte kryterium optymalizacyjne jest najmniejsze wówczas, gdy liczba wylosowanych aktywnych nośników reklamowych w ramach metody reprezentacyjnej

\footnotetext{
1 Minimalizacja wariancji estymatora.
} 
jest proporcjonalna do wszystkich jednostek występujących w danych strefach ich aktywności oraz do odchylenia średniego danej zmiennej w danej strefie.

W celu zapewnienia z góry założonego błędu badań $B_{b}$ dla określenia minimalnej liczby pomiarów ${ }^{2} n$ wykorzystano wzór (1):

$$
n \geq p \cdot(1-p) \cdot\left(\frac{z_{\alpha / 2}}{B_{b}}\right)^{2}
$$

gdzie:

$p$ - frakcja zaobserwowana w ograniczonej próbie; w przypadku braku danych stosując metodę reprezentacyjną $p=0,5$,

$z_{\alpha / 2}$ - wartość odchylenia względnego dla poziomu ufności odczytana z tablic dystrybuanty rozkładu normalnego:

$$
1-\alpha=0,95 \stackrel{\text { odpowiada }}{\longrightarrow} z_{\alpha / 2}=1,96
$$

Zatem minimalna ilość aktywnej powierzchni reklamowej wynosi:

$$
n \geq 0,5 \cdot 0,5 \cdot\left(\frac{1,96}{3 \%}\right)^{2}=1,067 \mathrm{~km}^{2}
$$

Rozmieszczenie próby w warstwach (sanockich strefach aktywności reklamowych) z aktualizacją roczną zawarto w tabeli 1 .

2 Przy nieznanym odchyleniu standardowym pomiarów aktywnych nośników reklamowych. 


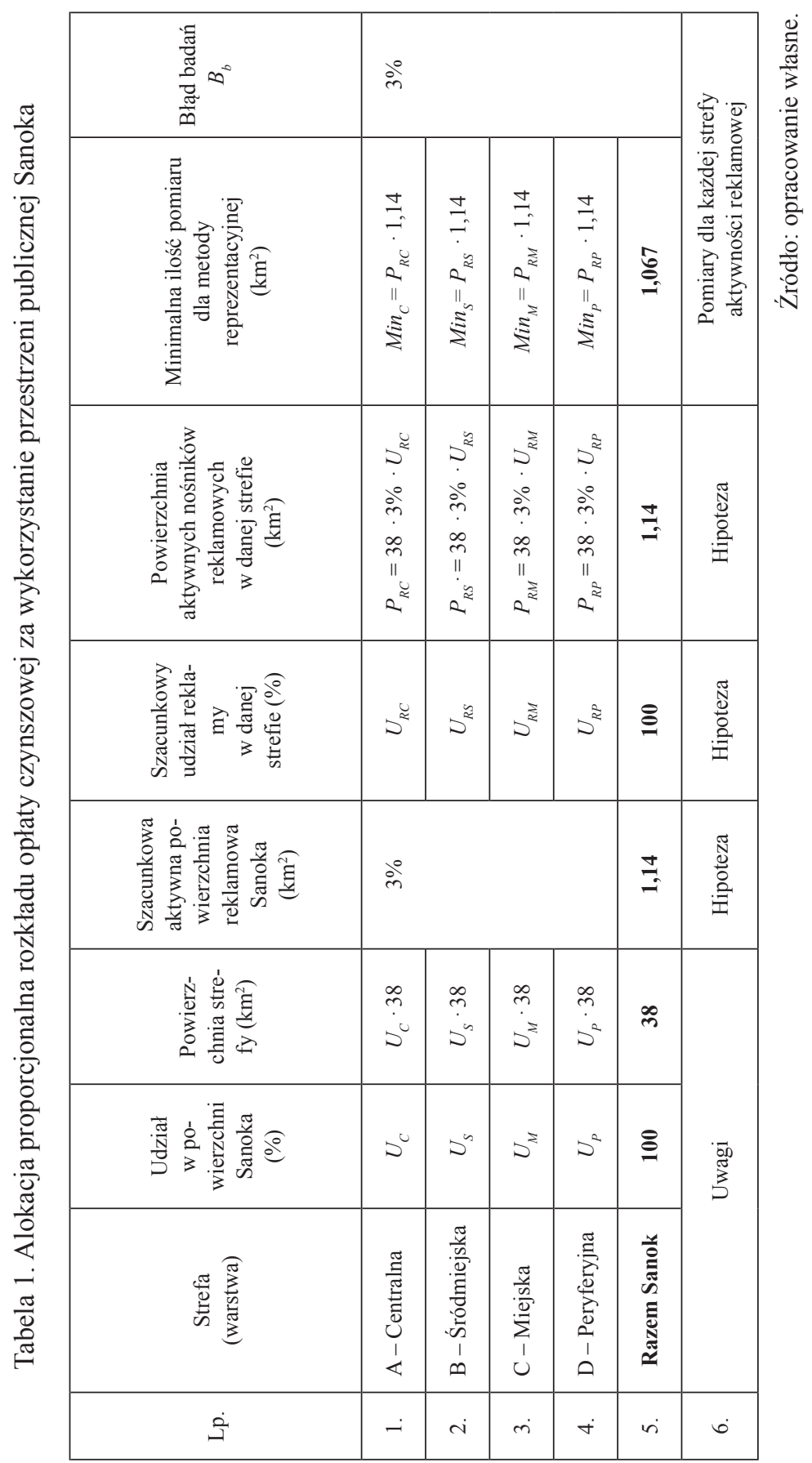




\section{Wprowadzenie opłaty na zasadzie formuły czynszowej ${ }^{3}$ od aktyw- nych nośników reklamowych $z$ tytułu wykorzystania przestrzeni publicznej}

Sanok jak wiele polskich miast jest miejscem niewątpliwie ,zalanym” reklamami wielkopowierzchniowymi. Wielu przedsiębiorców chce dotrzeć z przekazem nie tylko do mieszkańców, ale i do turystów. Dlatego też zasadne jest wprowadzenie niewielkiej, wyłącznie symbolicznej opłaty za dzierżawę przestrzeni publicznej z tytułu lokalizacji reklam. Wraz z wprowadzeniem tego typu opłaty zostana przyjęte regulacje zdecydowanie porządkujące w tej kwestii przestrzeń publiczną i ład architektoniczny.

Jak wynika ze wstępnych autorskich opracowań i wyników badań reprezentacyjnych ${ }^{4}$ opisany projekt ma swój głęboki sens ekonomiczny, to znaczy korzyści z wdrożenia są wielokrotnie większe niż koszty systemowej adaptacji.

Sanok zajmuje powierzchnię około $38 \mathrm{~km}^{2}$, czyli $38 \mathrm{mln}^{2}$. Zakładając powierzchnię dla tak zwanych aktywnych nośników reklamowych (w projekcie tylko takie podlegają opłacie na bazie stosownej deklaracji reklamowej5) wynoszącą tylko 3\%, otrzymano: 3\% x $38 \mathrm{mln} \mathrm{m}^{2}=1,14 \mathrm{mln} \mathrm{m}^{2}$ aktywnej powierzchni reklamowej. Przyjmując symboliczną opłatę wynoszącą 1 zł za $1 \mathrm{~m}^{2}$ aktywnej reklamy miesięcznie $^{6}$, szacunkowe wpływy do budżetu Sanoka wynoszą rocznie:

$1 \mathrm{zl} / \mathrm{m}^{2}$ x 1,14 mln $\mathrm{m}^{2}$ x 12 miesięcy $=13,7 \mathrm{mln} \mathrm{zł}$.

Przy planowanych dochodach Sanoka według danych za rok 2015 kwota 13,7 mln zł stanowi około 11,1\% dochodów ogółem ${ }^{7}$ i mogłaby sfinansować w zasadzie całe wydatki związane na przykład z gospodarką komunalną i ochroną środowiska - w budżecie ${ }^{8}$ Sanoka planowany wydatek na te cele to kwota około $13,5 \mathrm{mln} \mathrm{zł}$.

3 Opłata roczna w formie dzierżawy za wykorzystanie przestrzeni publicznej.

4 Koło Naukowe wdrażające metodę reprezentacyjną w sondażowym badaniu rynku reklam na terenie Sanoka. Koło działające w ramach PWSZ w Sanoku - Instytut Społeczno-Artystyczny, Zakład Ekonomii.

5 Na bazie oświadczenia woli - deklaracja reklamowa sporządzana w systemie internetowym.

6 Projekt zakłada szereg zwolnień i preferencji, na przykład z tytułu zachowania przez reklamodawcę standardu promocji Sanoka.

7 Planowany budżet za 2015 r. po stronie dochodowej wskazuje kwotę $123 \mathrm{mln}$ zł (http://esanok.pl/2014/projekt-budzetu-miasta-na-2015-rok-najwiecej-pochlonie-oswiata-oraz-pomoc-spoleczna-mp002.html).

\section{Ibidem.}


Z drugiej strony autorsko (na zasadzie próby losowej) analizowano skale, skutki obciążenia przedsiębiorców. Wniosek jest następujący: symboliczna stawka w wysokości $1 \mathrm{z} / \mathrm{m}^{2}$ miesięcznie za komercyjne wykorzystanie przestrzeni publicznej nie rujnuje przedsiębiorców, bowiem średnia roczna skala obciążenia przedsiębiorców wynosi średnio $10^{-5}$ rocznych przychodów ze sprzedaży.

Obecnie na gruncie przepisów samorządowych ${ }^{9}$ i centralnych ${ }^{10}$ zdaniem autorów wprowadzenie takiej opłaty nie wymaga zmian ustawowych, dlatego władze Sanoka powinny zabiegać o wdrożenie tej opłaty z uwzględnieniem analiz, opracowań naukowych, prezentacji, konsultacji środowiskowej na forum Związku Miast Polskich bądź Unii Metropolii Polskich.

\section{Etapy realizacji projektu sanockich reklam}

W projekcie tym wyróżnia się cztery etapy:

A - Analiza prawna możliwości wprowadzenia standaryzacji rynku reklamowego dla Sanoka ze szczególnym uwzględnieniem aspektu właścicielskiego.

B - Prezentacja i aspekt konsultacji środowiskowej standaryzacji rynku reklamowego dla Sanoka, w tym wykorzystanie potencjału naukowego i kadrowego Państwowej Wyższej Szkoły Zawodowej w Sanoku.

C - Etap realizacyjny, wdrożeniowy, w tym wprowadzenie dwóch kluczowych uchwał Zarządu Miasta Sanok ${ }^{11}$.

D - Analiza wyników i wnioski.

9 Wykorzystano pakiet ustaw i rozporządzeń tzw. okołosamorządowych, np. ustawa o ochronie i kształtowaniu środowiska z 31.01.1980 r. (Dz.U. nr 3, poz. 6, z późn. zm.) - odpowiedzialność samorządu za przestrzeń publiczną, http://isap.sejm.gov.pl/DetailsServlet?id=WDU19800030006.

10 Konwencja florencka. Dz.U. 2006, nr 14, poz. 98, http://isap.sejm.gov.pl/DetailsServlet?id= WDU20060140098. Projekt ustawy o zmianie niektórych ustaw w związku ze wzmocnieniem narzędzi ochrony krajobrazu - „ustawa krajobrazowa” - druk sejmowy nr 1525 z 1.07.2013 r. Ustawa o zmianie niektórych ustaw w związku ze wzmocnieniem narzędzi ochrony krajobrazu, Dz.U. 2015, poz. 774, http://isap.sejm.gov.pl/DetailsServlet?id=WDU20150000774.

11 Uchwała o ustanowieniu stref aktywności reklamowej z podziałem Sanoka na strefy:

A - centralną,

B - śródmiejską,

C - miejską,

$\mathrm{D}$ - peryferyjną.

Uchwała o wprowadzeniu opłat z tytułu lokalizacji aktywnych nośników reklamowych w strefach: A, $\mathrm{B}, \mathrm{C}$ i D. 


\section{Podsumowanie}

Zdaniem autorów funkcjonowanie rynku reklamowego dla Sanoka jest jedną z ważnych podstaw zarządzania na bazie oferowanej i poszerzającej się listy produktów i usług turystycznych oraz deficytu finansów publicznych. Czynnik reklamowy będzie odgrywał istotną rolę w bilansowaniu zysków będących udziałem wszystkich, w tym budżetów Skarbu Państwa i samorządu, podmiotów gospodarczych zarówno regionalnych, jak i przyłączonych.

Jak widać, system gospodarowania przestrzenią w Sanoku nie tylko przeżywa kryzys. Na terenach zamkniętych i otwartych obserwuje się bezładną ingerencję reklam, co zdecydowanie obniża jakość krajobrazu i wprowadza chaos architektoniczny. Otoczenie staje się coraz mniej funkcjonalne i przyjazne. W związku z powyższym istnieje dziś pilna potrzeba wprowadzenia racjonalnych zasad gospodarowania przestrzenią publiczną oraz uświadomienia jej wartości jako dobra wspólnego $\mathrm{z}$ wykorzystaniem opłat $\mathrm{w}$ formie czynszowej.

Niniejsze opracowanie stanowi początek cyklu artykułów poświęconych ważnemu problemowi kwantyfikacji przestrzeni publicznej.

\section{Literatura}

Becla, A., Czaja, S. (2004). Sposoby traktowania przestrzeni w teorii ekonomii. W: T. Łaguna (red.), Ekonomiczne aspekty gospodarki przestrzennej (s. 7-22). T. 1. Białystok: Ekonomia i Środowisko.

Borys, T. (red.). (2005). Wskaźniki zrównoważonego rozwoju. Warszawa-Białystok: Ekonomia i Środowisko.

Czekanowski, J. (1913). Zarys metod statystycznych. W zastosowaniach do antropologii. Warszawa.

Grabiński, T. (1994). Analiza stopnia informacyjności kostek danych. W: A. Zeliaś (red.), O zwiazkach demografii, statystyki i ekonometrii. Ksiegga jubileuszowa dla uczczenia 50-lecia pracy naukowo-dydaktycznej profesora Kazimierza Zająca (s. 68-84). Kraków: Wyd. AE w Krakowie.

Grabiński, T. (2003). Analiza taksonometryczna krajów Europy w ujęciu regionów. Kraków: Wyd. AE w Krakowie.

Filipiak B. (red.). (2009). Metodyka kompleksowej oceny gospodarki finansowej jednostki samorzadu terytorialnego. Warszawa: Difin. 
Filipiak, B. (2011). Finanse samorzadowe. Nowe wyzwania bieżace i perspektywiczne. Warszawa: Difin.

http:/esanok.pl/2014/projekt-budzetu-miasta-na-2015-rok-najwiecej-pochlonie-oswiataoraz-pomoc-spoleczna-mp002.html (27.11.2015).

http://isap.sejm.gov.pl/DetailsServlet?id=WDU19800030006 (27.11.2015).

Lubińska, T. (2010). Budżet a finanse publiczne. Warszawa: Difin.

Kleer, J. (2008). Sektor publiczny w warunkach współczesnych. OPTIMUM Studia Ekonomiczne, 4 (40), 34.

Kryk, B. (1999). Rola ekorozwoju w polityce ekologicznej i ekonomicznej państwa. W: S. Swadźba (red.), Systemy gospodarcze i ich ewolucja (s. 193-206). Katowice: Wyd. AE w Katowicach.

Kryk, B. (2004). Rachunek sozoekonomiczny działalności gospodarczej na przykładzie energetyki zawodowej regionu szczecińskiego. Szczecin: Wyd. US.

Meredyk, K. (2014). Ład gospodarczy jako kategoria ekonomiczna. W: P. Pysz, A. Grabska, M. Moszyński (red.), Spontaniczne i stanowione elementy ładu gospodarczego w procesie transformacji - dryf ładu czy jego doskonalenie? Warszawa: PTE.

Miłaszewicz, D. (2015). Propozycja oceny społecznej efektywności sektora publicznego na przykładzie UE. Studia Ekonomiczne. Zeszyty Naukowe Wydziałowe Uniwersytetu Ekonomicznego w Katowicach, 209, 127-135.

Neyman, J. (1934). On the Two Different Aspects of the Representative Method: The Method of Stratified Sampling and the Method of Purposive Selection. Journal of the Royal Statistical Society, 97 (4), 558-625.

Owsiak, S. (2006). Finanse publiczne. Teoria i praktyka. Warszawa: PWN.

Popławski, Ł. (2009). Uwarunkowania ekorozwoju gmin wiejskich na obszarach chronionych województwa świętokrzyskiego. Warszawa: PWN.

Steczkowski, J. (1995). Metoda reprezentacyjna $w$ badaniach zjawisk ekonomiczno-spotecznych. Warszawa: PWN.

Szewczuk, A., Zioło, M. (2008). Zarys ekonomii sektora publicznego, Szczecin: Wyd. Naukowe US.

Ustawa o planowaniu i zagospodarowaniu przestrzennym. Dz.U. 2003, nr 80, poz. 717.

Wilkin, J. (2010). Dobra dostarczane przez rolnictwo w świetle teorii dóbr publicznych. W: J. Wilkin (red.), Wielofunkcyjność rolnictwa. Kierunki badań, podstawy metodologiczne i implikacje praktyczne (s. 42-47). Warszawa: IRWiR PAN.

Zasępa, R. (1972). Metoda reprezentacyjna. Warszawa: PWE. 


\title{
QUANTIFICATION OF PUBLIC SPACE ON THE EXAMPLE OF SANOK
}

\begin{abstract}
The article presents the issue of the quantification of the public space and the fees for the use of the public space illustrated with the example of Sanok. Nowadays the problems connected with the spatial distribution of advertisements are treated in a different way, they are not most often considered with regard to spatial order. This issue, which is within the interest of spatial economics, is often omitted. The paper proves that the fees for the use of the public space is justified and does not burden entrepreneurs significantly, however, it can be an essential income to the budget of the self-government.
\end{abstract}

Translated by Bogusław Kaczmarczyk and Łukasz Popławski

Keywords: local development, public space, self-government JEL Code: H41 
